Review Article

\title{
Qualitative systematic review of homeopathic outcome studies in patients with HIV/AIDS
}

\author{
Subhranil Saha ${ }^{1}$, Malay Mundle ${ }^{2}$, ShubhamoyGhosh ${ }^{3}$, \\ MunmunKoley ${ }^{3}$, Sheikh Intaj Hossain ${ }^{3}$
}

\author{
${ }^{1}$ Clinical Research Unit (Siliguri), Central Council for Research in Homeopathy, India \\ 2Medical College, Kolkata, Government of West Bengal, India \\ ${ }^{3}$ M. B. H. Medical College \& Hospital, Government of West Bengal, India
}

\begin{abstract}
Background and aims: Systematic reviews of high-quality randomized controlled trials (RCTs) are crucial in evidence-based medicine (EBM). The aimof the present review was to investigatewhether there is enough evidence on the efficacy of homeopathy in individuals with HIV/AIDS based on clinical trials. Methods: The present is a criteria-based systematic review of cumulative research, and assessment of the methodological quality of published studies. The quality of the trials was evaluated using a list of validated and predefined criteria, and their outcomes were interpreted based on their quality. The main outcome measure was the methodological quality of the studies in terms of the threats to external, internal, construct, and statistical conclusion validity. Results: Among the 6 clinical outcome studies located, 3 were open-label, non-randomized, non-controlled trials, 2 were RCTs, and one was a single-set replication study. The trials were too few in number, and did not exhibit very high quality. The results showed a positive trend regardless of the quality of the trials, or the variety of homeopathic treatment used. The results of the present review may be complicated by publication bias. Conclusion: The currently available evidences donot suffice to infer definitive conclusions. Therefore, further evaluation of homeopathic treatment by means of appropriate RCTs with high methodological quality is required.
\end{abstract}

Keywords: Homeopathy, HIV/AIDS, clinical trials, literature review

\section{Introduction}

A systematic review is a survey of the literature focused on a research question to identify, appraise, select, and synthesize all the high-quality evidences relevant to that question. Systematic reviews of highquality randomized controlled trials (RCTs) are crucial in evidence-based medicine (EBM) [1]. An understanding of systematic reviews and how to implement them in practice is becoming mandatory for all healthcare professionals. In addition to health interventions, systematic reviews may assessclinical tests, public health interventions, social interventions, adverse effects, and economic evaluations [2,3]. Systematic reviews often, but not always, use statistical techniques (meta-analysis) to combine the results of the eligible studies, or at least score the levels of evidence basedon the methodology used. Systematic reviews apply objective and transparent approaches to the analysis of studies to minimize bias. While many systematic reviews are based on an explicit quantitative meta-analysis of the available data, qualitative reviews adhere to standards for gathering, analyzing, and reporting evidence[4]. 
Formulated originally by Samuel Hahnemann, homeopathy is a system of medicinebased on the principle of therapeutic similarity ("similia similibus curantur"), according to which, agents that induce in healthy individuals complaints resembling the ones in patients can cure the latter. Nevertheless, the claims made for the clinical efficacy of homeopathy are controversial, due to its use of drugs in high dilutions (HD). HD above $24 \mathrm{x} / 12 \mathrm{cH}$ are traditionally considered very unlikely to contain one single molecule of the starting substance [5], whereas according to homeopathic theory, higher dilutions exert stronger effects compared to the lower ones, allegedly as a function of the 'biological activity' they exhibit following dilution and agitation beyond Avogadro's number [6]. In the selection of the most similar medication, unusual symptoms that do not fit with the syndromes recognized by conventional medicine may eventually be more important than the regular ones. This is why homeopathy is a highly individualized therapy, anddifferent medications are prescribedto patients who would receive identical treatment in conventional medicine [5].

Few therapies have attracted more debate and controversy than homeopathy [7]. Proponents have quoted seemingly rigorous trials that suggest efficacy, while critics have little trouble in citing equally rigorous studies that imply the opposite. Although one approach to overcome such contradictions is to conduct systematic reviews and meta-analyses [7], following their superb meta-analysis from1997, Linde et al commented that no single clinical condition was identified in which homeopathy was clearly superior to placebo [7-10].

\section{Aims}

The aimof this review was to investigate whether there is enough evidence on the efficacy of homeopathy in patients with HIV/AIDS based on RCTs.

\section{Materials and methods}

A survey of the literature was performed in the following databases: National Library of Medicine (Medline/ via PubMed), The Cochrane Library, Centralized Information Service for Complementary Medicine (CISCOM), British Homeopathic Library (Hom-Inform), Central Council for Research in Homeopathy $(\mathrm{CCRH})$, India and cross-referencing between published papers. The search terms used were "homeopath...","homeopath... clinical trials on HIV/AIDS", "HIV and homeopathy", "AIDS and homeopathy", "meta-analysis in homeopathy", "systematic review in homeopathy", etc. Articles published from January 1990 toAugust 2012 were searched for. Only the bibliography of full articles published in peer-reviewed journals was scanned for further relevant references. Systematic reviews (with or without meta-analysis) of both controlled and non-controlled trials and clinical outcome studies on homeopathy involving patients with HIV/AIDS were included. All the articles were evaluated by the authors. All forms of homeopathic interventions were included, from classical single-remedy homeopathy to 'same formula in all patients' [11].

For inclusionin the present study, the articles had to meet the following criteria: (1) be written in English; (2) use a homeopathic intervention for a HIV/AIDS-related clinical condition; (3) assess the intervention outcomes using an empirical measure of some type; (4) be prospective; and (5) have sufficient information for scoringin a scale of threats to validity.

Each article was reviewed using established and previouslyvalidated criteria for judging threats to the characteristics and quality of empirical research. We also investigated whether the primary outcome was improved, unchanged, or made worse by homeopathic treatment. The reliability and accuracy of the present review were checked by another author (MM) neutral in regard to homeopathy. All the criteria were scored based on whether the high-quality items were present and adequate, or missing or inadequately met. Finally,we considered the number and percentage of the threats to external, internal, construct, and statistical conclusion validityin all the included studies [11-15] (Table 1). 
Table 1: Scale to measure threats to validity

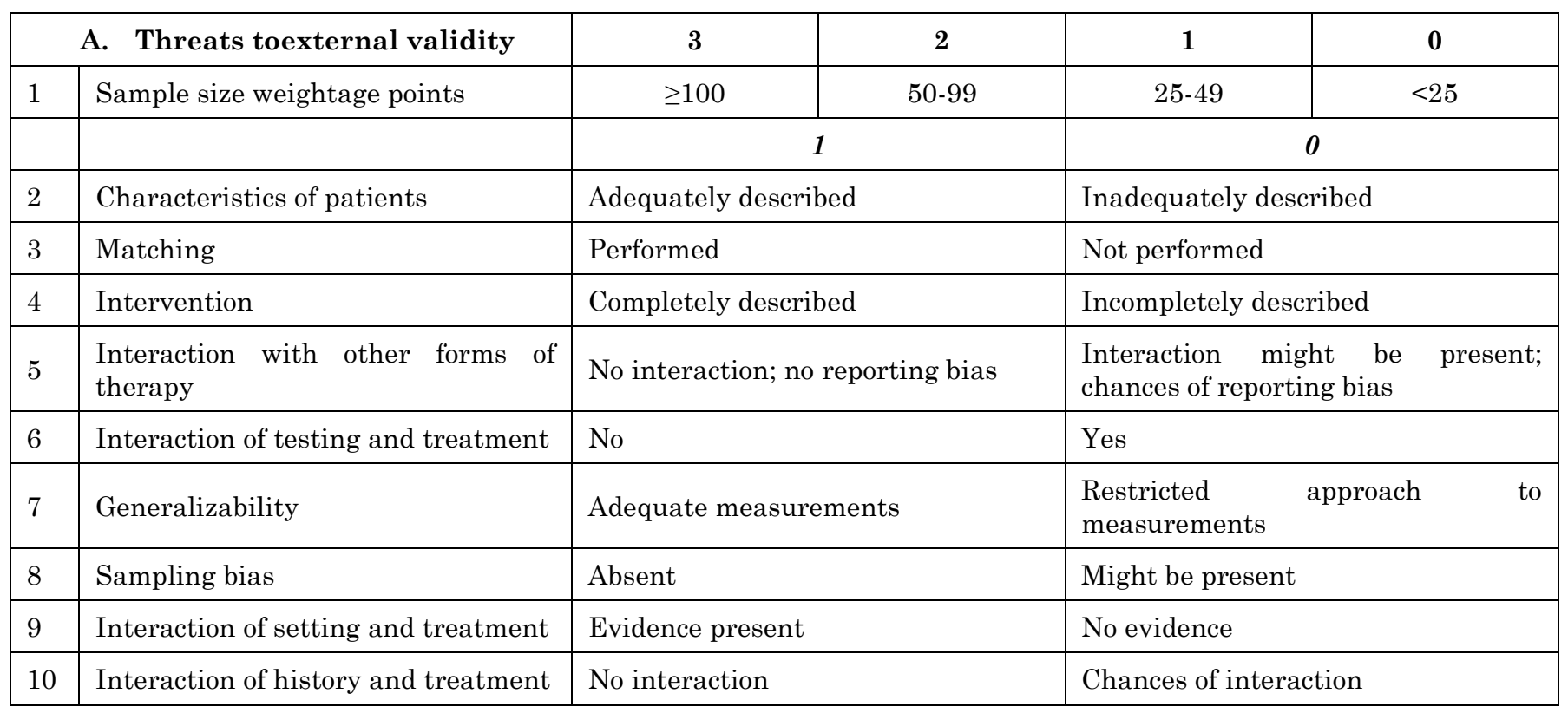

\begin{tabular}{|l|l|l|l|}
\hline \multicolumn{2}{|c|}{ B. Threats to internal validity } & \multicolumn{1}{|c|}{$\mathbf{1}$} \\
\hline 1 & Randomization & Correct & Pseudo or no randomization \\
\hline 2 & Blinding & Double blinding & Single or no blinding \\
\hline 3 & Study setting & Multicenter & Monocentric \\
\hline 4 & Replication studies & Present & Absent \\
\hline 5 & Attrition rate & Properly reported & Not properly reported \\
\hline 6 & History & Sequentially correct & Not correct \\
\hline 7 & Maturation & Performed & Not performed are not known to be \\
\hline 8 & Testing & Sensitive measures tested & $\begin{array}{l}\text { Measures aren } \\
\text { sensitive }\end{array}$ \\
\hline 9 & Instrumentation & Use of properly calibrated & $\begin{array}{l}\text { Poorly } \\
\text { instruments }\end{array}$ \\
\hline 10 & Statistical regression & instruments & Yes \\
\hline 11 & Mortality & No & $>30 \%$ \\
\hline 12 & Interaction with selection & $<30 \%$ & Yes \\
\hline 13 & Ambiguity of cause & No & Yes \\
\hline 14 & Diffusion of treatment & No & Chances \\
\hline 15 & Compensatory equalization & No chance & Yes \\
\hline 16 & Compensatory rivalry & No & Yes \\
\hline 17 & Resentful demoralization & No & Yes \\
\hline & & & \\
\hline
\end{tabular}




\begin{tabular}{|l|l|l|l|}
\hline C. & Threats to construct validity & & $\mathbf{1}$ \\
\hline 1 & Inadequate explication & No & Yes \\
\hline 2 & Mono-operation bias & Absent & Present \\
\hline 3 & Mono-method bias & No & Yes \\
\hline 4 & Hypothesis guessing & Not applicable & Chances \\
\hline 5 & Evaluation apprehension & Not probable & Chances \\
\hline 6 & Experimenter bias & Absent & May occur \\
\hline 7 & Confounding constructs & Range restriction present & Absent \\
\hline
\end{tabular}

\begin{tabular}{|c|c|c|c|}
\hline \multicolumn{2}{|c|}{$\begin{array}{l}\text { D. Threats to statistical } \\
\text { conclusion validity }\end{array}$} & 1 & $\mathbf{0}$ \\
\hline 1 & Low statistical power & High power of statistical test & Low power \\
\hline 2 & Violated assumption & Not applicable & May occur \\
\hline 3 & Fishing/error rate & Performed & Not performed \\
\hline 4 & Reliability of measures & Not applicable & May be present \\
\hline 5 & Reliability of treatment & No & Yes \\
\hline 6 & Random irrelevancies & No & Yes \\
\hline 7 & $\begin{array}{l}\text { Representative of random } \\
\text { heterogeneity }\end{array}$ & $\begin{array}{l}\text { Effort is evident as regards } \\
\text { heterogeneity of sample }\end{array}$ & Effort is not evident \\
\hline 8 & Data presentation & Amenable to review & Not amenable \\
\hline 9 & Effect measurement & Yes & No \\
\hline
\end{tabular}

Various methodological criteria toassess the threats to validity were considered in the scale:

1. Threats to external validity (maximum score $=12$ ): included sample size weightage point $(\geq 100: 3,50$ 99: 2, 25-49: 1 and <25: 0), description of the patients' characteristics (symptoms, duration, severity, etc.), matching of comparable baseline characteristics and potential variables, description of intervention (dose, duration, method of manufacture, etc.), interaction with other forms of therapy, interaction of testing and treatment (evidence that testing might be related with treatment so that the subjects test different after treatment), generalizability (due to limited measurement approach), sampling bias, interaction of setting and treatment (evidence(s) suggesting that treatment works in all settings), and interaction of history and treatment (evidence that the length of the study might have an impact on the findings).

2. Threats to internal validity (maximum score $=17$ ): included randomization, blinding, study setting, replication studies, reporting of attrition rate (withdrawal and drop-outs), history (repeated measurements without temporal control), maturation (repeated measurements without temporal control on developmentally sensitive outcomes), testing (measurements that are sensitive to the testing process), instrumentation, statistical regression (study of cases selected from extremes without control group), mortality (more than $30 \%$ of the sample not completing the study - migration out, refusal, non-compliance, etc.), interaction with selection (evidence that allocation to groups might interact with history, maturation, or testing), ambiguity of cause (an association that mightbe interpreted in either direction vis-à-vis cause and effect), diffusion of treatment (contact between experimental and control subjects), compensatory equalization (evidence that the groups have knowledge on the design and might equal things out), compensatory rivalry (evidence that groups 
have knowledge on the design and might compete with other group members), and resentful demoralization (evidence that one group feels disadvantaged by the allocation process).

3. Threats to construct validity (maximum score $=7$ ): included inadequate explication (evidence that the choice of measurement operations does not represent the construct), mono-method bias (use of only one approach in measurements, e.g. self-report for main outcome), hypothesis guessing (evidence that the subjects might attempt at guessing what the results should be, i.e. absence of appropriate blinding), evaluation apprehension (evidence that the subjects might become anxious during assessments), experimenter bias (absence of controls to keep interested parties from participating in the measurements), and confounding constructs (range restriction in measurement with levels of constructs).

4. Threats to statistical conclusion validity (maximum score $=9$ ): included low statistical power (any group $<10$ or correlations with fewer than 30 pairs), violated assumption (evidence of non-normal distributions with parametric statistics), fishing/error rate (more than 10 statistical tests without Bonferroni's similar correction), reliability of measures (failure to test, note, or reference information on measures), reliability of treatment (failure to test or note consistently the application of treatments), random irrelevancies (absence of effort to make measurements reasonably consistent), representative of random heterogeneity (absence of effort to ensure that the sample is reasonably heterogeneous), data presentation (data presented in such a manner that analysis mightbe checked by readers), and effect measurement (sensible, relevant, adequate, reproducible).

Two main outcomes were investigated in theRCTs: 'null hypothesis rejected' and 'null hypothesis not rejected'. The findings of studies in category 'null hypothesis rejected' were classified as 'positive' (i.e. for homeopathy) or 'negative' (i.e. against homeopathy) based on a two-tailed test. Positive trial was one where at least one outcome measure was significantly improved by homeopathy compared to placebo or alternative treatment ( $\mathrm{p}$ $<0.05)$. Negative study was one where at least one outcome measure was significantly inferior compared to placebo or alternative treatment $(\mathrm{p}<0.05)$. 'Null hypothesis not rejected'was the conclusion of studies where no significant intergroup difference in the outcome/s was evident $(\mathrm{p}>0.05)$.

\section{Results}

A total of five clinical trials, 3 non-controlled, and 2 controlled, a single-set replication study, and one review article [16] evaluating the effects of homeopathic interventions in patients with HIV/AIDS were located. All the studies were published in peer-reviewed journals. Most studies $(n=3,60 \%)$ were government funded, and the others (20\%) were technically assisted by private foundations.

Both controlled studies reported the age and gender of participants, but none their race or ethnicity. Only one randomized trial was replicated once in 8 different cities of the United States over 8-16 weeks [17]. In all the studies the sample was less than 100.

All the studies were prospective. Fromthe 2 controlled trials, one used placebo [18], and the other used 2 active controls (natural and conventional antiviral therapy) [17]. Both studies used matched control groups. None of these studies described the sampling frame used; however, they considered potentially confounding variables in their design. The threats to validity of these trials are described tables 2 and 3. 
Table 2: Scoring of the methodological quality of the trials

\begin{tabular}{|c|c|c|c|c|c|c|c|}
\hline & \multirow{2}{*}{$\begin{array}{c}\text { Trials } \\
\text { (in chronological } \\
\text { order) }\end{array}$} & \multicolumn{6}{|c|}{ Consideration of threats to validity } \\
\hline & & $\begin{array}{l}\text { External } \\
\text { validity } \\
(\max =12)\end{array}$ & $\begin{array}{l}\text { Internal } \\
\text { validity } \\
(\max =17)\end{array}$ & $\begin{array}{l}\text { Construct } \\
\text { validity } \\
(\max =7)\end{array}$ & $\begin{array}{l}\text { Statistical } \\
\text { conclusion } \\
\text { validity } \\
(\max =9) \\
\end{array}$ & $\begin{array}{l}\text { Total score } \\
(\max =45)\end{array}$ & Score $\%$ \\
\hline 1 & Bissuel et al, 1995 & 5 & 13 & 5 & 7 & 30 & 66.67 \\
\hline 2 & $\begin{array}{l}\text { Rastogi } \\
\text { et al, } 1999\end{array}$ & 7 & 14 & 7 & 8 & 36 & 80 \\
\hline 3 & $\begin{array}{l}\text { Danninger et } a l \text {, } \\
2000\end{array}$ & 6 & 9 & 5 & 7 & 27 & 60 \\
\hline 4 & Brewitt et al, 2000 & 7 & 14 & 5 & 6 & 32 & 71.11 \\
\hline 5 & Brewitt et al, 2002 & 9 & 15 & 6 & 8 & 38 & 84.44 \\
\hline
\end{tabular}

Table 3: Characteristics and results of trials

\begin{tabular}{|c|c|c|c|c|c|}
\hline \multicolumn{2}{|c|}{ Trials \& Investigators } & \multirow{2}{*}{$\begin{array}{c}\text { Methodology } \\
\text { score } \%\end{array}$} & \multirow{2}{*}{\begin{tabular}{l}
\multicolumn{1}{c}{ Indication } \\
Desensitization of \\
hypersensitivity to prophylactic \\
trimethoprim- \\
sulphamethoxazole (TMP-SMX) \\
therapy in HIV-infected \\
patients
\end{tabular}} & \multirow{2}{*}{$\begin{array}{c}\text { Intervention } \\
\text { TMP-SMX } 9 \text { or } 15 \mathrm{cH}\end{array}$} & \multirow{2}{*}{$\begin{array}{r}\text { Results } \\
\text { positive }\end{array}$} \\
\hline $\begin{array}{l}\text { Non- } \\
\text { controlled } \\
\text { trials }\end{array}$ & $\begin{array}{l}\text { Bissuel et al, } \\
1995\end{array}$ & & & & \\
\hline & $\begin{array}{l}\text { Danninger et al, } \\
2000\end{array}$ & 60.0 & $\begin{array}{l}\text { Decrease of circulating immune } \\
\text { complexes (CIC) in healthy } \\
\text { research subjectsand HIV- } \\
\text { positive patients, with } \\
\text { significant increase of CD } 4 \\
\text { lymphocytes, CD4/CD } 8 \text { ratio } \\
\text { and improvement of HIV- } \\
\text { related symptoms }\end{array}$ & $\begin{array}{l}\text { Lysate of } \\
\text { Staphylococcus } \\
\text { aureus strain } \\
\text { Cowan I } 12 \mathrm{cH}\end{array}$ & positive \\
\hline & $\begin{array}{l}\text { Brewitt et al, } \\
2000\end{array}$ & 71.1 & $\begin{array}{l}\text { Physical, immunologic, } \\
\text { neurologic, metabolic, and } \\
\text { quality-of-life benefits from } \\
\text { homeopathic growth factors in } \\
\text { patients with HIV/AIDS }\end{array}$ & $\begin{array}{l}\text { Combination of IGF- } \\
1, \text { PDGF-BB, TGF } \beta 1 \text {, } \\
\text { and GM-CSF } 30 \mathrm{cH} \text {, } \\
200 \mathrm{cH} \text {, and/or } 1000 \mathrm{cH}\end{array}$ & positive \\
\hline \multirow[t]{2}{*}{$\begin{array}{l}\text { Randomized } \\
\text { controlled } \\
\text { trials }\end{array}$} & $\begin{array}{l}\text { Rastogi et al, } \\
1999\end{array}$ & 80.0 & $\begin{array}{l}\text { Holistic approach to patients } \\
\text { with HIV/AIDS anddecreased } \\
\text { CD } 4 \text { and/or CD8 count }\end{array}$ & $\begin{array}{l}\text { Single individualized } \\
\text { homeopathic remedy }\end{array}$ & positive \\
\hline & $\begin{array}{l}\text { Brewitt et al, } \\
2002\end{array}$ & 84.4 & $\begin{array}{l}\text { Physical, immunologic, } \\
\text { neurologic, metabolic, and } \\
\text { quality-of-life benefits from } \\
\text { homeopathic growth factors in } \\
\text { patients with HIV/AIDS }\end{array}$ & $\begin{array}{l}\text { Combination of IGF- } \\
1, \text { PDGF-BB, TGF } \beta 1 \text {, } \\
\text { and GM-CSF } 30 \mathrm{cH} \text {, } \\
200 \mathrm{cH} \text {, and/or } 1000 \mathrm{cH}\end{array}$ & positive \\
\hline
\end{tabular}


Most of the studies reported on the reliability of measures, but failed to report the response rates, i.e. the number of patients screened compared to the number who entered the study. One single studyreported the attrition rate.

All the studies reported statistically significant improvement as a result of treatment. However, the probability of positive outcomes was significantly lower when random allocation was performed compared to lack of randomization $\left(\mathrm{x}^{2}=7.71, p=0.0055\right)$.

Significant threats to validity occurred in all the analyzed studies [19 - 21], especially in regard to the external validity, as all the studies had small samples, and none was multicenter, nor replicated. Therefore, the results are difficult to generalize beyond the study sample. Surprisingly, the scores of internal, construct, and statistical conclusion validity were not very low, indicating that homeopathic research is not appreciably inferior in regard to control of bias and systematic error.

\section{Discussion}

In trials with limited numbers of participants, there is no guarantee that randomization will divide the known and unknown confounders equally among the experimental and control groups. In addition, publication bias may be less likely in studies with large numbers of participants [6]. Other major criteria of methodological soundness are randomization and double-blindness. When prognostic factors of the illness other than the intervention under study are insufficiently known, random allocation to the contrasted treatments is useful to ensure comparable prognoses. Double-blindness is important to keep the intervention exactly the same in the contrasted groups except for the homeopathic treatment, and to ensure unbiased assessment of the effects. This is especially important in regard to the relief of subjective symptoms, as it is often the case in homeopathic treatments [6].

The overall quality of the homeopathic trials was unsatisfactory. Homeopathic clinical research is clearly in its childhood,asmost studies use poor sampling and measurement techniques, few subjects, single sites, virtually no replication, and practically no overlap in the investigated conditions. Many of these problems might be corrected, even in the case ofa so-called 'holistic' paradigm given sufficient research expertise, support and method. To build credibility within the medical research community, multiple replications and/or extensions using the same or similar approaches to the treatment of same or similar medical conditions are necessary. Multisite research with larger sample sizes is essential to improve the confidence level and generalizability of the findings [11].

The comprehensive clinical interviews and long-term followup commonly included in the homeopathic management of cases increase the patient-doctor interaction, and are likely to enhance expectancy and placebo effects. These factors might hinder the detection and isolation of the effects induced by homeopathic drugs when they occur. Combined with the small sample sizes, these factors might falsely increase the reportof negative studies. Therefore, the effect of the homeopathic clinical procedures should be studied separately from the investigation of the eventual specific (non-placebo) effects of homeopathic drugs. The former should be assessed in pragmatic randomized trials comparing homeopathic to standard treatment, and the latter by means of simple laboratory or clinical models easy to repeat by independent investigators [11].

The lack of appropriate frameworks to conduct large trials with homeopathic drugs is one, but not the only challenge posed to high-quality research. Critical systematic reviewsof studiesare able to identify the areas those need to be improved. Quality guidelines for research in homeopathy have already been published. More critical peer-review of homeopathic studies complying with those and other guidelines might improve the quality of research. The methodological pitfalls of homeopathic trials ought to be carefully addressed by investigators if the quality, credibility, and usefulness of research in homeopathy are to improve [11]. 
Due to problems with the external validity, the results of the analyzed studies are not likely to be generalizable beyond the study population. However, the scores of internal validity quality were not always appreciably worse compared to conventional therapy [11].

More rigorous trials in homeopathy are associated with smaller effect sizes compared to non-randomized, noncontrolled trials. The overall effect becomes even more insignificant when possible publication bias is also taken into account, or only high-quality trials are included in reviews or analyses [7-10, 22].

Key issues that must be addressed in future homeopathic studies include the research question posed, its associated trial design, and the outcome measures chosen. Non-placebo-controlled designs may adopt measures of 'quality of life'. Placebo-controlled trials should take acute medical conditions into consideration (as opposed to chronic conditions, where the selection of treatment according to various homeopathic schools is based on the patients so-called 'constitutional' character), where prescribing might be relatively simpler due to the narrower range of indicated remedies, and the effects quickly andmore accurately ascertained. Testing the effects of homeopathy as adjuvant to conventional medication is also another option currently being considered by investigators. Equivalence trials offer another promising way forward [23, 24].

\section{Conclusion}

The hypothesis that any homeopathic remedy induces clinical effects in patients with HIV/AIDS significantly different from placebo, or superior to other control interventions is not adequately supported by systematic reviews. There is a dearth of high-quality studies supporting their effectiveness and safety. Until more compelling results are available, homeopathy cannot be viewed as an evidence-based form of therapy in HIV/AIDS. However, homeopathic outcome studies may represent respectable endeavors to clarify the effects of homeopathic care by producing quantifiable, reproducible and/or constructive data, provided research is performed more rigorously and systematically than up to the present time.

New trials of homeopathic medicines against placebo are no longer considered a research priority [25]. The question whether ultra-molecular dilutions might exhibit any measurable physical/biological effect based on electromagnetic waves [26] or 'conglomerates'/'aggregates' of nanoparticles retaining encrypted information of the starting substance in the interfacial water [27-30] is best tackled by means of advanced materials science concepts and complex experimental tools. However, there is still a role for pragmatic trials comparing the effect and cost effectiveness of orthodox and homeopathic treatments [25].

\section{References}

[1] "What is EBM?" Centre for Evidence Based Medicine. http://www.cebm.net/index. aspx?o=1914. Retrieved 2011-06-17.2009-11-20.

[2] Systematic reviews: CRD's guidance for undertaking reviews in health care. York: University of York, Centre for Reviews and Dissemination, 2008. ISBN 978-1-900640-47-3. Retrieved 2011-06-17.

[3] Petticrew M, Roberts H. Systematic reviews in the social sciences. Wiley Blackwell, 2006.

[4] Herman J. Ader; Gideon J. Mellenbergh; with contributions by Hand D J.Methodological quality (chapter 3) in Advising on Research Methods: A consultant's companion. Johannes van Kessel Publishing. ISBN 97890-79418-02-2. (2008).

[5] Thomas, J.; Harden, A; Oakley, A; Oliver, S; Sutcliffe, K; Rees, R; Brunton, G; Kavanagh, J. "Integrating qualitative research with trials in systematic reviews". BMJ $328(7446):$ 1010- 
2. doi:10.1136/bmj.328.7446.1010. PMC 404509. PMID 15105329.//www.ncbi.nlm.nih.gov/pmc/articles/PMC40 4509/. (2004)

[6] Jos Kleijnen, Paul Knipschild, Gerber terRiet. Clinical trials of homeopathy.BMJ February 9, 1991; 302: 316-23

[7] Ernst E. A systematic review of the systematic reviews of homeopathy.Br J ClinPharmcol, 54, 577-82, 2002.

[8] Linde K, Clausius N, Ramirez G, et al. Are the clinical effects of homeopathy placebo effects? A metaanalysis of placebo-controlled trials. Lancet 1997 Sep 20; 350 (9081): 834-843

[9] Linde K, Melchart D. randomized controlled trials of individualized homeopathy: a state-of-the-art review. J Alt Complementar Med 1998; 4: 388

[10] Linde K, Scholz M, Ramirez G, et al. Impact of study quality on outcome in placebo controlled trials of homeopathy. J Clin Epidemiol 1999; 52: 631-636

[11] Jonas WB, Anderson RL, Crawford CC, Lyons JS. A systematic review of the quality of homeopathic clinical trials.BMC Complementary and Alternative Medicine 2001, 1:12 doi: 10.1186/1472-6882-1-12; http://www.biomedcentral.com/1472-6882/1/12

[12] Haynes RB, Sackett DL, Guyatt GH, Tugwell P. Clinical Epidemiology, 2005. Lippincott Williams \& Wilkins; pp. 31; ISBN: 978-0-7817-4524-6.

[13] Olivo SA, Macedo LG, Gadotti IC, Fuentes J, Stanton T, Magee DJ. Scales to Assess the Quality of Randomized Controlled Trials: A Systematic Review. Physical Therapy, 2008; 88(2). ISSN: 0031-9023. http://findarticles.com/p/articles/mi_hb237/is_2_88/ai_n29412210/pg_1

[14] Jadad AR, Alejandro R, Enkin, Murray. Randomized Controlled Trials: Questions, Answers and Musings; Blackwell, 2007 (2). ISBN: 978-1-4051-3266-4.

[15] Jadad AR, Moore RA, Carroll D, Jenkinson C, Reynolds DJM, Gavaghan DJ, McQuay HJ. Assessing the quality of reports of randomized clinical trials: is blinding necessary? Controlled Clinical Trials, 1996, 17 (1): 1-12. doi:10.1016/0197-2456(95)00134-4. PMID 8721797.

[16] Dana Ullman. Controlled clinical trials evaluating the homeopathic treatment of people with Human Immunodeficiency Virus or Acquired Immune Deficiency Syndrome.The J of Altern \& Complement Med, 2003, 9(1), 133-41

[17] Brewitt B, Traub M, Hangee-Bauer C, Patrick L, Standish LJ. Homeopathic growth factors as treatment for HIV: Recovery of homeostasis and functional immune system. AIDS and Complementary and Alternative Medicine: Current Science and Practice, Philadelphia: Churchill Livingstone, 2002:126-146

[18] Rastogi DP, Singh VP, Singh V, Dey SK, Rao K. Homeopathy in HIV infection: a trial report of doubleblind placebo controlled study. Br Hom J (1999), 88, 49-57

[19] Bissuel F, Cotte JB, Crapanne P, Rougier P, Schlienger I, Trepo C. Trimethoprimsulphamethoxazolerechallenge in 20 previously allergic HIV-infected patients after homeopathic desensitization. AIDS 1995; 9:407-408. 
[20] DanningerT, GallenbergerK, KraelingJ. Immunologic changes in healthy probands and HIV infected patients after oral administration of Staphylococcus aureus 12c: a pilot study. British Hom J (2000) 89, 10615.

[21] Brewitt B, Traub M, Hangee-Bauer C, Patrick L, Standish LJ. Homeopathic growth factors: A low cost survival strategy for functional immunity and improved metabolism. XIIIth International AIDS Conference.Monduzzi Editore, Italy, July 2000, pp. 81-87.

[22] Ernst E. Pittler MH. Re-analysis of previous meta-analysis of clinical trials of homeopathy. J Clin Epidemiol 2000; 53: 1188.

[23] RT Mathie. The research evidence base for homeopathy: a fresh assessment of the literature. Homeopathy (2003) 92, 84-91

[24] Jones B, Jarvis P, Lewis JA, Ebbutt AF. Trials to assess equivalence: the importance of rigorous methods. Br Med J 1996; 313: 36-39.

[25] Gene Feder, Katz T. Randomized controlled trials for homeopathy: who wants to know the results? BMJ 2002, 324: 498-99[26]Montagnier L, Aïssa J, Ferris S, Montagnier JL, Lavallée C. Electromagnetic signals are produced by aqueous nanostructures derived from bacterial DNA sequences. Interdiscip Sci Comput Life Sci (2009) 1: 81-90. DOI: 10.1007/s12539-009-0036-7

[27] Upadhay RC, Nayak C. Homeopathy emerging as nanomedicine. Int J High Dilution Res 2011; 10(37): 299-310

[28] Chikramane PS, Suresh AK, Bellare JR, Kane SG. Extreme homeopathic dilutions retain starting materials: a nanoparticulate perspective. Homeopathy 2010 (99), 231-242. doi:10.1016/j.homp.2010.05.006, available online at http://www.sciencedirect.com

[29] Rao ML, Roy R, Bell I. Characterizations of the structure of ultra dilute sols with remarkable biological properties. Materials Letters 2008 (62), 1487-1490. Available online at www.sciencedirect.com. www.elsevier.com/locate/matlet

[30] Rao ML, Roy R, Bell I, Hoover R. The defining role of structure (including epitaxy) in the plausibility of homeopathy.Homeopathy 2007 (96), 175-182. DOI: 10.1016/j.homp.2007.03.009; available online at http://www.sciencedirect.com

\title{
Revisão sistemática qualitativa de estudos de desfecho do tratamento homeopático em pacientes com HIVIAIDS
}

\begin{abstract}
RESUMO
Introdução e objetivos: As revisões sistemáticas de estudos randomizados controlados (RCTs) são essenciais na medicina baseada em evidências (MBE). O objetivo deste estudo foi estabelecer se há evidência suficiente a favor da eficácia da homeopatia em pacientes com HIV/AIDS a partir de ensaios clínicos. Métodos: Trata-se de uma revisão sistemática da pesquisa acumulada baseada em critérios, com avaliação da qualidade metodológica dos estudos publicados. A qualidade dos estudos foi avaliada mediante uma lista de critérios validados e predefinidos e os resultados foram interpretados a partir de sua qualidade. $\mathrm{O}$ desfecho principal analisado foi a qualidade metodológica dos estudos nos termos das ameaças a sua validade externa, interna, de construto e conclusão estatística. Resultados: Dos 6 estudos clínicos informando resultados que foram localizados, 3 eram ensaios abertos, não randomizados e não controlados, 2 eram RCTs e
\end{abstract}


um era um estudo de replicação com um único grupo. O número de ensaios clínicos localizados foi muito pequeno e de qualidade não muito alta. Os resultados apontaram uma tendência positiva independentemente da qualidade dos ensaios e do tipo de tratamento homeopático utilizado. Os resultados desta revisão podem sofrer de viés de publicação. Conclusão: As evidências disponíveis atualmente são insuficientes para conclusões definitivas. Portanto, o tratamento homeopático ainda precisa de maior avaliação, através de RCTs adequados e de alta qualidade metodológica.

Palavras-chave: Homeopatia, HIV/AIDS, ensaios clínicos, revisão da literatura

\section{Revisión sistemática cualitativa de estudios de resultado del tratamiento homeopático en pacientes con VIH/SIDA}

\section{RESUMEN}

Introducción y objetivos: Las revisiones sistemáticas de estudios controlados aleatorizados (ECC) son esenciales en la medicina basada en evidencia (MBE). El objetivo de este estudio fueevaluar si hayevidencia suficiente a favor de la eficacia de la homeopatía en pacientes con VIH/SIDA a partir de ensayos clínicos. Métodos: Se trata de una revisión sistemática basada en criterios de la investigación acumulada, con evaluación de la calidad metodológica de los estudios publicados. La calidad de los estudios fue evaluada mediante una lista de criterios validados y predefinidos ylos resultados fueron interpretados a partir de su calidad. El principal resultado medido fue la calidad metodológica de los estudios expresa como amenazas a su validez externa, interna, de constructo y conclusión estadística. Resultados: De los 6 estudios clínicos de resultados localizados, 3 eran ensayos abiertos, no aleatorizados y no controlados, 2 eran ECC y uno un estudio de replicación con un único grupo. El número de estudios clínicos localizados fue muy bajo y su calidad no muy alta. Los resultados indican una tendencia positiva independiente de la calidad de los estudios y el tipo de tratamiento homeopático efectuado. Los resultados de esta revisión pueden adolecer de sesgo de publicación. Conclusión: La evidenciaactualmente disponible no permite inferir conclusiones definitivas. El tratamiento homeopático necesita mayor evaluación mediante ECC adecuados y de alta calidad metodológica.

Palabras clave: Homeopatía, VIH/SIDA, estudios clínicos, revisión de la literatura

\section{(c)) BY-NC-ND Licensed to GIRI}

Received: December 10 th 2012 ; Revised: March 06 ${ }^{\text {th }}, 2013$; Published: March 30 ${ }^{\text {th }}, 2013$.

Correspondence author: SubhranilSaha, drsubhranilsaha@hotmail.com.

How to cite this article: Saha S, Mundle M, Ghosh S, Koley M, HossainSI. A Qualitative Systematic Review of the Homeopathic Outcome Studies in Patients with HIV/AIDS.Int J High Dilution Res [online]. 2012 [cited YYYY Month dd]; 12(42): <\#from-\#to.> Available from: http://. 